This is an author produced version of a paper published in Dermatologic Therapy. This paper has been peer-reviewed but does not include the final publisher proofcorrections or journal pagination.

Citation for the published paper:

Wallengren, Joanna

"Neuroanatomy and neurophysiology of itch."

Dermatol Ther. 2005 Jul-Aug;18(4):292-303.

http://dx.doi.org/10.1111/j.1529-8019.2005.00041.x

Access to the published version may require journal subscription.

Published with permission from: Blackwell Synergy 


\title{
NEUROANATOMY AND NEUROPHYSIOLOGY OF ITCH
}

\author{
Joanna Wallengren \\ Department of Dermatology, Clinical Sciences, \\ University Hospital, Lund, Sweden
}

\author{
Joanna Wallengren, \\ Department of Dermatology \\ University Hospital \\ SE-221 85 Lund \\ Sweden \\ Tel: +46 46173152 \\ Fax: +46 46173947 \\ e-mail: Joanna.Wallengren@derm.lu.se
}




\begin{abstract}
The specific pathway of "pure", histaminergic, itch is traced from the mechanoinsensitive nerve fibers in the skin to their central cortical projections. Neuropathic itch created at different levels of this anatomical pathway is reviewed. In this review we discuss damage to pruritoceptors in the skin, entrapment syndromes, damage to spinal ganglia, nerve root impingement, injury of the spinal cord and cerebral damage in the distribution of the middle cerebral artery, capsula interna or thalamus. Itch in inflamed skin resulting from interactions between nerve transmitters and other mediators of inflammation is described.
\end{abstract}

Key words: itch, pruritus, neuropathic, histamine, neuropeptides, capsaicin 


\section{Introduction}

Itch has tormented animals and humans for thousands of years, especially when infestations were common due to poor hygiene and crowded living. It is often the main symptom of skin disease and a common reason for consulting a dermatologist. Itch-alleviating therapies were practised long before dermatology achieved the status of a medical discipline.

For a long time itch was regarded as a weak variant of pain, although it can only be elicited in the skin or mucous membranes. In 1927, Lewis proposed that histamine, discovered in 1910, causes itching in inflammatory skin disease (1). Another milestone was the pioneering work of Shelly and Arthur in the 1950s; they used spiculas of the fruit of mucuna pruriens (cowhage) to show where in the skin the itch is most easily elicited (itch points) (2). They found that inserting the spiculas in the dermo-epidermal juncture area induced the strongest itch. Winkelmann showed this to be the location the location of sensory unmyelinated nerve fibres in the skin (3). In mid 1960s Melzak and Wall proposed a gate theory showing how stimulation of pain inhibits itch (4). Experiments in the beginning of 1980 showed that increasing the intensity of itch induced a stronger itch but no pain (5). This led to conclusion that itch and pain are separate sensations and that they are transmitted along different pathways. This division promoted more research into itch, which for a long time had been in the shadow of pain, a big brother with a massive annual health bill.

Researchers started looking for "itch receptors" in the periphery and for an "itch centre" in the cortex. Although such single entities have not been defined, considerable progress has been made on classifying different forms of itch and understaning the underlying mechanisms. In this review we follow the neuronal pathway for histamine-induced itch. Cutaneous reactions induced by endogenous 
pruritogenic mediators and their response to common drugs such as antihistamines, local anaesthetics, indomethacin and capsaicin are described. Neuropathic itch at different levels of the neuronal pathway is described.

\section{The anatomical framework for itch conduction}

A neuronal pathway of itch described in this section has been elucidated using histamine as a model for "pure itch".

\section{Cutaneous nerve fibres conducting itch}

Sensory neurons or primary afferent neurons have a unipolar cell body located in the dorsal root ganglia (DRG) of spinal nerves or in the sensory ganglia of cranial nerves. The axons of neurons that conduct itch are unmyelinated C-fibres that end in the skin at the dermo-epidermal junction, sometimes penetrating into the epidermis as free endings. The sensory nerve fibres are mainly peptidergic, with substance P (SP) and calcitonin gene-related peptide (CGRP) as main transmitters (6). Recently, Schmelz and co-workers have used iontophoresis of histamine to show, that the Cfibres that convey itch comprise about $5 \%$ of the afferent $\mathrm{C}$-fibres in human skin. Itch-mediating C-fibers have slow conduction velocities $(0.5 \mathrm{~m} / \mathrm{s})$ and large innervation territories (a diameter of $85 \mathrm{~mm}$ on the lower leg) compared to polymodal C-fibres (7). They respond to thermal stimuli but are insensitive to mechanical stimuli.

Pruritogenic agents or physical factors like thermal stimuli will activate C-fibres and lead to the release of transmitters in the skin through an axon reflex (neurogenic inflammation, see below). The depletion of nerve transmitters in the peripheral afferents will stimulate synthesis of new nerve transmitters in the cell bodies of the spinal ganglia (8). The orthodromic nerve transmission of sensory C-fibres will be 
conducted through the peripheral processes of the spinal nerves to the spinal ganglia and from there through the central processes of the spinal nerves to the dorsal root of the spinal cord (Figure 1).

\section{Spinal processing of itch}

Most of the nociceptive afferents terminate in the superficial region of the dorsal horn. In experiments on rat, intracutaneous administration of histamine, nicotine and capsaicin as well as topical application of mustard oil and noxious heat resulted in activation of most superficial dorsal horn neurons (9).

Recently, neurons selectively sensitive to histamine, "itch specific neurons", have been identified in cat (10). Mechano- and heat-insensitive neurons were identified using antidromic stimulation from thalamus and a collision of antidromic and orthodromic impulses. Later these neurons were tested with histamine applied iontophoretically to the skin. Neurons sensitive to histamine were found to be located in the most superficial part of the dorsal horn-lamina I spinothalamic tract (lamina I SST). These neurons cross over the spinal cord to the contralateral side and their projections will terminate in the lateral part of thalamus. These neurons have been shown to lack ongoing discharge (common in pain conduction neurons) and to have slow central conduction velocities (10).

\section{Spino-thalamico-cortal transmission of itch}

Primates seem to have a direct pathway from lamina I spinothalamic tract neurons through midbrain to two sites in thalamus: the ventral medial nucleus and the medial dorsal nucleus (9). The role of thalamus in the emotional processing pain is well known while data diverges concerning its role in the modulation of itch.

Experiments using positron emission tomography (PET) regional cerebral blood flow measurements in response to histamine prick test provocation by Drzezga et al 
did not show any involvement of thalamus while similar experiments by Mochizuki et al on histamine applied by iontophoresis demonstrated activation of thalamus (11, 12).

However, studies using the PET technique have shown that several cortical areas such as the frontal, parietal and cingulated cortex are involved in the processing of itch $(11,12,13)$. Two main pathways from thalamus to cortex may be distinguished (9). Neuronal projections from the ventral medial nucleus in thalamus terminate in area $3 \mathrm{a}$ in sensorimotor cortex, while neurons from the medial dorsal nucleus in thalamus terminate in the anterior cingulate cortex (9). Both these cortical areas have been found to be activated when tracing histamine-induced itch and scratching (11, $12,13)$. Involvement of the motor cortex explains the urge to scratch contingent on the perception of unpleasant itch. Scratching, in fact, has for a long time been recognised as the most reliable measurement of itch (14). Activation of the anterior cingulate cortex, a relay for emotional processing of an array of feelings, romantic love included, explains the affective component of itch (15). A schematic route of itch transmission is shown in Figure 1.

\section{Cutaneous elicitation of itch}

The C-type primary afferent fibres that conduct itch are not only sensitive to neurotransmitters but also to histamine and to other inflammatory mediators (13).

\section{Pruritoceptive nerve fibres and their transmitters}

Many nerve transmitters are involved in the conduction of itch. Several neurotransmitters are co-localized and may be switched several times on the way from the skin up to the cortex (16). Like all neuropeptides, most transmitters occur both in the neurons of the peripheral and the central nervous system. Serotonin and 
histamine occur in cellular structures in the skin but act as nerve transmitters in the neurons of the central nervous system. The C-fibres present in the epidermis and papillary dermis are peptidergic, with tachkinins substance P (SP) and neurokinin A (NKA) and calcitonin gene-related peptide (CGRP) as main transmitters (Figure $2 a)(6)$.

Substance $\mathbf{P}$, SP, consisting of 11 amino acid residues, is encoded by the same gene as NKA, consisting of 10 amino acid residues (17). Generally, SPimmunoreactive nerve fibres are few or moderate in number, except for instance in the skin of fingertips, where they are numerous. SP-containing nerve fibers are also known to form a network around sweat glands and blood vessels (6). Activation of C-fibres leads to release of transmitters in the skin through an axon reflex, resulting in an inflammatory response called neurogenic inflammation (Figure 3). Hagermark and Fjellner have studied itch induced by several neuropeptides; including SP and VIP, and found that they produce flare, wheal and itch (Figure 3)(18). SP-evoked flare is dependent upon an axon reflex, since pre-treatment of the skin with lidocaine greatly diminishes the response (19). SP-flare is also partly inhibited by indomethacin, blocking synthesis of prostaglandin, suggesting an interaction between these mediators (20). The flare response to SP, a model for neurogenic inflammation, has been shown to depend on several physiological factors. There is a regional variation of the flare response, which is most prominent on the thorax and less so at more distal locations (20). The flare response diminishes with increasing age and in conditions of physical stress, and its magnitude varies with the time of day, being greater at night (21). The depletion of histamine from dermal mast cells by compound $48 / 80$ greatly reduces the flare response to SP, suggesting flare to be dependent on histamine (18, 19). There is also evidence that histamine $\mathrm{H} 3$ receptors are located on peripheral 
endings of substance P nerve fibres (22). Close contacts between mast cells and nerve fibers have been demonstrated $(23,24,25)$. Tachykinin receptors are of three subtypes- NK1, NK2 and NK3- and SP mainly activates the NK1 receptor (17). Two SP-antagonists, spantide I and spantide II, have been shown to have reduced type I and type IV allergic reactions $(26,27)$

Calcitonin gene-related peptide, CGRP, is a 37-amino acid peptide that is encoded by the same gene that codes for calcitonin (28). CGRP is the most abundant of all neuropeptides in human skin and is often found to be co-localised with SP (Figure 2a) (6). In human skin, CGRP induces slowly developing local reddening (duration of several hours) but no itch (personal experience)(19). The erythema does not seem to be mediated by mast cell histamine or by $\mathrm{C}$ fibre tachykinins, as it is not suppressed by pre-treatment with either $\mathrm{H} 1$ receptor antagonist, mepyramine, mast cell histamine liberator, compound $48 / 80$ or by lidocaine treatment. These findings are in accordance with the finding that calcitonin gene-related peptide does not induce activation of mast cells and release of histamine (29). The long-lasting and widespread vascular effects of CGRP may reflect a gradual diffusion of the peptide, which conceivably exerts direct effects on blood vessels. CGRP is considered the main mediator of sensory nerve fibers, being the main mediator of capsaicin induced erythema in human skin (30). If CGRP is injected intracutaneously together with SP, the duration of the response will shorten (31). Based on the differential biological activities of various CGRP analogs, the CGRP receptors have been classified into CGRP1 and CGRP2 (28). CGRP-antagonist, CGRP/8-37/, with affinity for CGRP-1 receptor has been shown to have dual activity (depending on concentration) on allergic contact dermatitis (32). 


\section{Capsaicin as a pharmacological tool}

Capsaicin is the active substance in chilli peppers and is responsible for their burning taste. Other spicy plants (ginger, black pepper etc) also contain similar agents, but capsaicin is the most potent and most thoroughly studied. Capsaicin is a highly potent burning substance that selectively stimulates nociceptives and causes release of neuropeptides from afferent temperature-sensitive neurons, both peripherally and within the spinal cord (33). Repeated cutaneous administration of capsaicin abolishes the flare response to substance $\mathrm{P}$ reflecting release of substance $\mathrm{P}$ and impairment of the axon reflex $(34,20)$. The flare reaction recovers after about eight weeks (28). Capsaicin evoked flare response can be inhibited by lignocaine and indomethacin (21). Systemic, subcutaneous administration of capsaicin in laboratory animals, depletes neuropeptides like CGRP, and induces skin ulcers (35).

Recently the capsaicin receptor has been cloned and is now named transient receptor vanniloid1 (TRPV1) (33). Expression of heat-activated vanilloid receptor, VR 1, binding capsaicin, have been found not only in cutaneous sensory nerves but also in mast cells and epithelial cells (Fig $2 b)(36,37)$. The vanilloid receptor belongs to the TRP family of excitatory ion channels. Another member of this family has been described recently, namely the cold- and menthol-sensitive receptor, CMR1 (38).

CMR1 and VR 1 have been shown to co-exist sometimes in the same primary afferent neurons and promote to thermo sensations in a wide range of temperatures 8-28 and $>50^{\circ} \mathrm{C}$ respectively (38). These findings explain why heating and cooling influence perception of itch.

\section{Neuropeptides in inflammatory and pruritic skin disease}

Using radio-immuno assay, high levels of substance $\mathrm{P}$ (SP), somatostatin, vasoactive intestinal peptide (VIP), calcitonin gene-related peptide (CGRP) and 
neuropeptide Y (NPY) were found in spontaneous blisters from inflammatory skin disease as well as in suction blisters induced on inflamed, itchy skin $(6,39,40)$. Increased density of several neuropeptides has been shown in the lesional skin of atopic dermatitis and of psoriasis $(41,42)$. The vascular responses induced by intradermal injection of histamine, SP, NKA and CGRP were shown to be lower compared to controls (43). This hyporesponsiveness has been interpreted as being due to tachyphylaxis.

VIP has been shown to coexist with acetyl choline in autonomic nerve fibres (44). Acetylcholine induces itch in patients with atopic dermatitis while it induces a burning sensation in controls (45). It may explain why atopic skin itches when sweating. Increased concentrations of VIP have been found in the skin of atopic patients.

\section{Pruritogenic mast cell mediators}

Histamine has been known to be a main itch-inducing substance for many years (1). Development of antihistamines has had an enormous impact not only on the research into itch but also on its treatment, as they have come to be the most commonly used antipruritic drugs. The following is an attempt to find an explanation.

Accumulation of mast cells has been shown in many pruritic, inflammatory skin conditions (46). In the clinical situation histamine is not released alone but, together with other mediators stored or produced after activation of mast cells like chymase and tryptase, platelet-activating factor, leukotriens, prostaglandin D2 and interleukins 4, 56 , and 8 .

Histamine induces a flare, weal and itch that are significantly inhibited by the $\mathrm{H} 1$ antagonist, mepyramine and only partly by the $\mathrm{H} 2$ receptor inhibitor, cimetidine (47). This experiment explains why $\mathrm{H} 1$ antagonists are widely used in the treatment of itch. 
Today $\mathrm{H} 3$ and $\mathrm{H} 4$ receptors are also known (48). The H3 receptors are mainly expressed in the neurons of the peripheral and central nervous system while H1, H2 and $\mathrm{H} 4$ receptors are found on mast cells (48). The itch and flare reactions induced by histamine are also reduced by pretreatment with a local anaesthetic, lidocaine, indicating that mast cells and nerve fibres constitute a functioning unit.

Mast cell chymase is released together with histamine upon degranulation of mast cells. Rat mast cell chymase was shown to induce flare, weal and itch in human skin. This itch response was greatly decreased by local depletion of histamine using compound 48/80 (49). Mast cell tryptase is also released along with histamine upon degranulation of mast cells and it seems to be an important mediator of itch by its activation of proteinase activated receptor 2 present on sensory nerve fibres and endothelial cells (50).

Activation of mast cells stimulates synthesis of several metabolites of arachidonic acid. Platelet activating factor is synthesized in activated mast cells. When injected intracutaneously it induces a dose-dependent flare and itch, which is inhibited by the H1 receptor antagonist mepyramine (51). Leukotriens, LTC4 and LTD4 are potent vasodiators but do not induce a flare and weal response (52) The antileukotrien, montelukast has proved to be effective in treating of pruritus in urticaria (53).

\section{Other pruritogenic mediators of inflammation}

Mast cell mediators, especially histamine, seem to be very important in the perception of itch. However, clinically there are many types of itch that fall outside this cathegory, simply by not responding to antihistamines.

Prostaglandins participate in the generation of itch (54). Prostaglandin D is produced by mast cells, being released in urticaria (55). In the skin prostaglandin E2 
induces a slowly progressing erythema (Figure 3). Prostaglandin E2 induces weak itch and potentates itch induced by histamine (56). Indomethacin, by blocking synthesis of prostaglandin, inhibits the flare response to substance $\mathrm{P}$ to approximately $60 \%$ and to bradykinin to one third (20). The effect of prostaglandins is also dependent on functioning innervation since local anaesthetic, lidocaine suppresses the erythema induced by prostaglandin E2 by approximately $30 \%(20)$.

Bradykinin injected intracutaneously induces itch that is weaker than histamineinduced itch (57). The flare response to bradykinin is greatly reduced by pre-treatment with the $\mathrm{H} 1$ receptor inhibitor (mepyramine) and the local anaesthetic (lidocaine) and the prostaglandin synthesis inhibitor (indomethacin) $(20,58)$. Bradykinin B1 and B2 receptors have been found on sensory nerve fibers (59).

Serotonin injected intradermally induces itch that is less potent than that of histamine and is enhanced by PGE2 (60). Serotonin type 3(5-HT3) receptor is present both in the peripheral and central nervous system, but the serotonin receptor antagonist, tropisetron, has however not proved to be effective in experinentally induced itch, nor in renal itch (61).

Interleukins, especially IL-2, are known to produce itch. Immunotherapy with IL-2 in the treament of cancer was noted regulary to cause itching (62). On the other hand cyclosporin, a potent inhibitor of IL-2 production by lymphocytes, is effective in treating itch in atopic dermatitis and other forms of severe pruritus $(63,64)$.

\section{Regulation of pruritoceptive activity in the skin}

The interactions between sensory nerve fibres, their transmitters and other pruritogenic mediators are illustrated in Figure 3. This cascade of events is dependent on the the innervation territories of the neurons, on the density of mast cells and on 
the concentration of inflammatory mediators. This in turn will depend on synthesis, release and degradation of the substances involved. For example, substance P and bradykinin are degraded by neutral endopeptidase and angiotensin converting enzyme (62). Tryptase cleaves CGRP while chymase and tryptase are degraded by proteases $(66,50)$. This dynamic system contributes to the regulation of the inflammatory response and to the maintenance of tissue integrity.

\section{Itch in skin with only slight or no clinical inflammation}

In itchy skin disease with an ongoing inflammation, the inflammatory mediators will be continuously produced, fuelling the firing of sensory nerve fibres. Sometimes, however, the degree of inflammation does not correlate with the severity of itch.

Patients with prurigo nodularis may literally dig their skin when scratching, even if the inflammation is not pronounced. The most impressive and pathognomonic finding of prurigo nodularis is the presence of thick nerve fibre bundles and fine, reticularly arranged terminal nerve fibres (67). As early as 1899 Johnston wrote in the Archives of Dermatology that the number of hypertrophic nerve fibres in prurigo lesions is increased.

It has also been demonstrated that uremic patients undergoing hemodialysis develop a proliferation and sprouting of nerve fibers in the epidermis (68). Both prurigo nodularis and uremic pruritus can be successfully treated with capsaicin, supporting the importance of the altered cutaneous innervation $(69,70,71)$.

\section{“Grenz sensations”: painful itch or itchy pain}

In many clinical states of localized itch, burning and tingling are intermingled.

There is often no clinical inflammation in the skin and the symptoms will be elicited 
by spontaneous firing of neurons without a noxious or pruritogenic stimulus (Figure

5). The predominating sensation will decide whether the patient seeks a dermatologist or a neurologist. Many of the following entities have been described by neurologists.

\section{Peripheral neuropathic itch}

Some localised itchy disorders have no clinical signs of inflammation. Here the neurons can start firing either spontaneously or due to pressure on the nerve, which is the case in entrapment syndromes (Figure 5B).

\section{Notalgia paresthetica}

Notalgia paresthetica was first described by Astwazaturow1934 as focal, burning itch on the medial border of the scapula (72). One explanation is that the thoracic nerves at the level of $\mathrm{T} 2$ to $\mathrm{T} 6$ penetrate the spinal muscle at a right angle which predisposes them for injury from mild insults (73). Another explanation that has been suggested is an impingement of the nerve root as confirmed by MRI (74). In addition, Springall et al have found an increased number of dermal sensory nerve fibres in notalgia paresthetica (75). Notalgia paresthetica can be successfully treated with capsaicin (76).

\section{Meralgia paresthetica}

Meralgia paresthetica with burning, tingling, and numbness on the anterolateral thigh. The cause is thought to be due to entrapment of the lateral femoral cutaneous nerve by a fibrous band (77). Obesity, pregnancy or backpacking are known to predispose or precipitate it.

\section{Backpacking-induced paresthesias}

Meralgia, digitalgia paresthetica and tarsal tunnel syndrome are most common. Paresthesias were reported in 96 of 280 long-distance backpackers. As significant risk 
factor was the distance of marching, more than 2000 miles and the symptoms resolved after hiking (78).

\section{Marcher's digitalia paresthetica}

Marcher's digitalia paresthetica was first described by Wartenberg in 1954. Tarsal tunnel syndrome is a lesion of the posterior tibial nerve due to repetitive dorsiflexion of the ankle. It is common among runners and mountain climbers. It was described in Israeli military recruits after 4 weeks of training, and at nine month-follow up most were asymptomatic (79).

\section{Cheiralgia paresthetica}

Cheiralgia paresthetica describes itch confined to the radial aspect of the lower arm and is due to the entrapment of the radial nerve. Two cases secondary to handcuff placement were reported (80). In patients where mechanical causes have been excluded, diabetes mellitus should be considered as a possible cause (81).

\section{Brachioradial pruritus}

Brachioradial pruritus, a localised itching of the skin on the dorso-lateral aspect of the arms, was first described by Waisman in Florida in 1968 as "solar pruritus of the elbows" (82). We have found that brachioradial pruritus may be localised not only on the arms but also on the shoulders or neck (83). Another report, from South Africa, by Heyl in 1983, concerned 14 patients with brachioradial pruritus (84). Five of these patients had a history of neck trauma or arthritis. The author suggested that some or even most cases of brachioradial pruritus might be due to nerve injury in the cervical spine or to nerve compression by other structures. This explanation was supported by Fisher who found that four of his 23 patients with brachioradial pruritus suffered from degenerative cervical spine disease (85). Goodkin, Wingard and Bernhard, in addition 
to reporting on 22 patients of their own, reviewed the literature on brachioradial pruritus (86). They found that 30 of 98 patients suffered from cervical spine disease. On the other hand, two reports from Hawaii of a total of 110 patient, supporting the photoneurological theory, the term being coined by Walcyk and Elpern $(87,88)$. In their study concerning 42 patients with brachioradial pruritus, Walcyk and Elpern found $13 \%$ to have a history of cervical arthritis, $19 \%$ a history of neck trauma and 10 $\%$ to be seeing a chiropractor (87). Fifteen of the patients were screened radiologically. All who were over 50 years of age showed pathological cervical radiographic findings whereas $60 \%$ of those under 50 years of age showed no abnormailites (87). In a study on 68 brachioradial pruritus patients, Knight and Hayashi found "neck pain" to be present in six of them only (85). In many patients living in temperate climates, pruritus appears during the summer, remits in the winter and relapses the following summer $(89,83)$. Brachioradial pruritus can be successfully treated with capsaicin $(90,83)$.

We have shown that brachioradial pruritus is associated with a reduction in epidermal nerve fibres and enlargement of nerve fibers in the papillary dermis (91). These findings strikingly resemble the ones we observed in the skin after serial phototherapy (Figure 4a, b) (92). In brachioradial pruritus, the cutaneous innervation of itchy skin normalises during the symptom-free period. The results indicate that brachioradial pruritus can be elicited by exposure to sunlight or by heat.

The question is if prolonged exposure to sunlight is enough to elicite brachioradial pruritus or if spinal pathology alone can explain the symptoms. Bernhard suggested that both cervical spine disease and sunlight induced damage to cutaneous nerve endings are important underlying contributors and trigger factors, one setting stage for the other (93). 


\section{Double crush syndromes?}

This suggestion might point towards a double crush syndrome (94). This theory has been postulated by Upton and McComas 1979. They studied 115 patients with carpal tunnel syndrome or cubital tunnel syndrome. 81 of these patients exhibited clinical symptoms of a neural lesion of the neck. According to their hypothesis, the distal part of an axon is easily damaged when another part of that axon is under compression. This theory might explain several of the mono-neuropathies described above.

\section{Spinal neuropathic itch}

A lesion can also be located in the spinal ganglia like in herpes infection and postherpetic neuralgia (Figure 5C)(95). Here the neurons become activated without the involvement of peripheral nerve endings. Inflammation at this level can enhance neuronal excitability, causing repetitive activation of the C-fibers (fig 4). Chronic postherpetic neuralgia can be successfully treated with capsaicin (96). There can also be a lesion located in the spinal cord, as in the case with the burning sensation induced by treatment with thalidomide (97). Here the neurons can start firing spontaneously due to injury induced by the drug.

\section{Cerebral neuropathic itch}

Itch can also be induced by a cerebral lesion. Unilateral pruritus has been described in eleven patients with cerebral damage due to stroke or infection in the distribution of the middle cerebral artery, capsula interna or thalamus on the contralateral side $(98,99,100)$. One patient with unilateral pruritus due to a stroke in the parietal lobe has also been described (101). In these cases pruritus is induced by a spontaneous firing of damaged neurons. 


\section{Generalized itch due to altered concentrations of transmitters of}

\section{$\operatorname{mood}$}

Not only organic lesions in the brain can cause itch but also several psychiatric disorders (102). Itch also influences mood, some patients get agitated, others become depressed (103). Neurotransmitters of depression like dopamine and serotonine are associated with pruritic conditions $(104,60)$. In addition, serotonin is associated with compulsive behaviours like scratching (105). Treatment of Parkinson disease using dopaminergic drugs is related to hallucinations, tactile delusions included (104). Opioid pathways are associated with anxiety and with nociception (106). Opiate mediated pruritus is often severe and may be induced either by endogenous opiates (secondary to liver disease) or to morphine administration. It was first described by Bernstein et al, who described relief of intractable pruritus with naltrexone, interpreting the effect as a central mechanism on opioid receptors in the CNS (107). The opioid system is also involved in uremic pruritus which also can be suppressed by naltrexone $(108,109)$.

\section{Conclusion}

A distinct pathway of "pure" itch has been determined. In the skin, histamine seems to be the main mediator of itch as depletion of histamine reduces experimental itch induced by several other mediators. In this light it is surprising that antihistamines are not more effective in treatment of clinical itch. Description of burning and tingling itch, a "grenz sensation," suggests neuropathic origin. Localized itch, associated with trauma to peripheral nerves, resolves often after some time of resting. 


\section{Acknowledgements}

The present paper was supported by grants from Vardal Foundation, Skane County Foundation and Welander \& Finsen Foundation.

\section{References}

1. Lewis T, Grant RT, Marvin HM. Vascular reaction of skin to injury. Part X: The intervention of a chemical stimulus illustrated especially by flare. The response to Faradism. Heart 1927; 14: 139-160.

2. Shelley WB, Arthur RP. The neurohistology and neurophysiology of the itch sensation in man. Arch Dermatol 1957; 76: 296-323.

3. Winkelmann RK. Some sensory nerve endings in the skin. Arch Derm Syphysiol 1955; 71: 373-378.

4. Melzack R, Wall PD. Pain mechanisms: a new theory. Science. 1965: 150:971-9.

5. Torebjörk HE, Ochoa J. Pain and itch from C-fiber stimulation. Soc Neurosci Abstr 1981; 7: 228 .

6. Wallengren J, Ekman R, Sundler F. Occurrence and distribution of neuropeptides in the human skin. Acta Derm Venereol (Stockh) 1987; 67: 185-192.

7. Schmelz M, Schmidt R, Bickel A, Handwerker HO, Torebjörk HE. Specific CReceptors for Itch in Human Skin. J Neurosci 1997; 17: 8003-8008.

8. Donnerer J, Schuligoi R, Stein C. Increased content and transport of substance P and calcitonin gene-related peptide in sensory nerves innervating inflamed tissue: evidence for a regulatory function of nerve growth factor in vivo. Neuroscience. 1992; 49: 693-698. 
9. Jinks SL, Carstens E. Superficial dorsal horn neurons identified by intracutaneous histamine: chemonociceptive responses and modulation by morphine. J Neurophysiol. 2000; 84: 616-627.

10. Andrew D, Craig AD. Spinothalamic lamina I neurones selectively responsive to cutaneous warming in cats. J Physiol. 2001; 537: 489-495.

11. Drzezga A, Darsow U, Treede RD, Siebner H, Frisch M, Munz F, Weilke F, Ring J, Schwaiger M, Bartenstein P. Central activation by histamine-induced itch: analogies to pain processing: a correlational analysis of $\mathrm{O}-15 \mathrm{H}_{2} \mathrm{O}$ positron emission tomography studies. Pain 2001; 92: 295-305.

12.Mochizuki H, Tashiro M, Kano M, Sakurada Y, Itoh M, Yanai K. Imaging of central itch modulation in the human brain using positron emission tomography. Pain 2003; 105: 339-346.

13. Hsieh JC, Hagermark O, Stahle-Backdahl M, Ericson K, Eriksson L, StoneElander S, Ingvar M. Urge to scratch represented in the human cerebral cortex during itch. J Neurophysiol. 1994; 72: 3004-3008.

14. Rees JL, Laidlaw A. Pruritus: more scratch than itch. Clin Exp Dermatol 1999; 24: 490-493.

15. Bartels A, Zeki S. The neural basis of romantic love. Neuroreport. 2000; 11: 3829-3834.

16. Riedel W, Neeck G. Nociception, pain, and antinociception: current concepts. Z Rheumatol. 2001; 60: 404-415.

17. Severini C, Improta G, Falconieri-Erspamer G, Salvadori S, Erspamer V. The tachykinin peptide family. Pharmacol Rev. 2002; 54: 285-322. 
18. Fjellner B, Hagermark O. Studies on pruritogenic and histamine-releasing effects of some putative peptide neurotransmitters. Acta Derm Venereol. 1981; 61:245-250. 19. Wallengren J, Håkanson R. Effects of substance P, neurokinin A and calcitonin gene-related peptide in human skin and their involvement in sensory mediated responses. Eu J Pharmacol 1987; 143: 267-273.

20. Wallengren J, Håkanson R. Effects of capsaicin, bradykinin and prostaglandins in the human skin. Br J Derm 1992;126:111-117.

21. Wallengren J, Håkanson R, Andren Sandberg A. Physiological factors influencing the SP-evoked flare and wheal in human skin. Advances in Pain Research and Therapy 1992; 20: 63-69.

22. Ohkubo T, Shibata M, Inoue M, Kaya H, Takahashi H. Regulation of substance P release mediated via prejunctional histamine H3 receptors. Eur J Pharmacol. 1995; 273:83-88.

23. Padawer J. Studies on mamalian mast cells. Trans N Y Acad Sci 1957; 19: 690. 24. Botchkarev VA, Eichmuller S, Peters EM, Pietsch P, Johansson O, Maurer M, Paus R. A simple immunofluorescence technique for simultaneous visualization of mast cells and nerve fibers reveals selectivity and hair cycle--dependent changes in mast cell--nerve fiber contacts in murine skin. Arch Dermatol Res 1997; 289: 292302.

25. Hagforsen E, Nordlind K, Michaelsson G. Skin nerve fibres and their contacts with mast cells in patients with palmoplantar pustulosis. Arch Dermatol Res. 2000; 292:269-274.

26. Wallengren J. Substance P antagonist inhibits immediate and delayed type cutaneous hypersensitivity reactions. Br J Dermatol 1991; 124: 324-328. 
27. Babu RJ, Kikwai L, Jaiani LT, Kanikkannan N, Armstrong CA, Ansel JC, Singh

M. Percutaneous absorption and anti-inflammatory effect of a substance P receptor antagonist: spantide II. Pharm Res. 2004; 21:108-113.

28. Wu D, Doods H, Arndt K, Schindler M. Development and potential of nonpeptide antagonists for calcitonin-gene-related peptide (CGRP) receptors: evidence for CGRP receptor heterogeneity. Biochem Soc Trans. 2002; 30: 468-473.

29. Huttunen M, Harvima IT, Ackermann L, Harvima RJ, Naukkarinen A, Horsmanheimo M. Neuropeptide- and capsaicin-induced histamine release in skin monitored with the microdialysis technique. Acta Derm Venereol. 1996; 76: 205-209. 30. Sann H, Pierau FK. Efferent functions of C-fiber nociceptors. Z Rheumatol. 1998: 57 Suppl 2: 8-13.

31. Brain SD, Williams TJ. Substance P regulates the vasodilator activity of calcitonin gene-related peptide. Nature. 1988; 335:73-75.

32. Wallengren J. Dual effects of CGRP-antagonist on allergic contact dermatitis in human skin. Contact Dermatitis.2000: 43: 137-143.

33. Szolcsanyi J. Forty years in capsaicin research for sensory pharmacology and physiology. Neuropeptides. 2004; 38: 377-384.

34. Bernstein JE, Swift RM, Soltani K, Lorincz AL. Inhibition of axon reflex vasodilatation by topically applied capsaicin. J Invest Dermatol. 1981; 76: 394-395. 35. Wallengren J, Chen D. Local skin lesions in rat after subcutaneous deposition of capsaicin. Skin Pharmacology and Applied Skin Physiology 2002; 15: 147-158.

36. Stander S, Moormann C, Schumacher M, Buddenkotte J, Artuc M, Shpacovitch V, Brzoska T, Lippert U, Henz BM, Luger TA, Metze D, Steinhoff M. Expression of 
vanilloid receptor subtype 1 in cutaneous sensory nerve fibers, mast cells, and epithelial cells of appendage structures. Exp Dermatol. 2004; 13:129-139.

37. Wallengren J, Sundler F. Brachioradial pruritus is associated with a reduction of cutaneous inervation which normalizes during the symptom-free remissions. J Am Acad Dermatol 2005; 52: 142-145.

38. McKemy DD, Neuhausser WM, Julius D. Identification of a cold receptor reveals a general role for TRP channels in thermosensation. Nature. 2002; 416: 52-58.

39. Wallengren J, Ekman R, Möller H. Substance P and vasoactive intestinal peptide in bullous and inflammatory skin disease. Acta Derm Venereol (Stockh) 1986; 66: $23-28$.

40. Pincelli C, Fantini F, Romualdi P, Lesa G, Giannetti A. Skin levels of vasoactive intestinal polypeptide in atopic dermatitis. Arch Dermatol Res. 1991; 283:230-2.

41. Pincelli C, Fantini F, Massimi P, Girolomoni G, Seidenari S, Giannetti A. Neuropeptides in skin from patients with atopic dermatitis: an immunohistochemical study. Br J Dermatol. 1990;122: 745-50.

42. Staniek V, Doutremepuich J, Schmitt D, Claudy A, Misery L. Expression of substance P receptors in normal and psoriatic skin. Pathobiology. 1999; 67(1):51-4.

43. Giannetti A, Girolomoni G. Skin reactivity to neuropeptides in atopic dermatitis. Br J Dermatol. 1989; 121(6):681-8.

44. Lindh B, Hokfelt T. Structural and functional aspects of acetylcholine peptide coexistence in the autonomic nervous system. Prog Brain Res. 1990; 84:175-191.

45. Rukwied R, Heyer G. Administration of acetylcholine and vasoactive intestinal polypeptide to atopic eczema patients. Exp Dermatol. 1999; 8: 39-45. 
46. Asboe-Hansen G. A survey of the normal and pathological occurrence of mucinous substances and mast cells in the dermal connective tissue in man. Acta Derm Venereol (Stockh) 1950; 30: 338-347.

47. Hagermark O, Strandberg K, Gronneberg R. Effects of histamine receptor antagonists on histamine-induced responses in human skin. Acta Derm Venereol. 1979; 59:297-300.

48. Lippert U, Artuc M, Grutzkau A, Babina M, Guhl S, Haase I, Blaschke V, Zachmann K, Knosalla M, Middel P, Kruger-Krasagakis S, Henz BM. Human skin mast cells express H2 and H4, but not $\mathrm{H} 3$ receptors. J Invest Dermatol. 2004; 123: 116-123.

49. Hagermark O, Rajka G, Bergvist U. Experimental itch in human skin elicited by rat mast cell chymase. Acta Derm Venereol. 1972; 52:125-128.

50. Steinhoff M, Neisius U, Ikoma A, Fartasch M, Heyer G, Skov PS, Luger TA, Schmelz M. Proteinase-activated receptor-2 mediates itch: a novel pathway for pruritus in human skin. J Neurosci. 2003; 23: 6176-6180.

51. Fjellner B, Hagermark O. Experimental pruritus evoked by platelet activating factor (PAF-acether) in human skin. Acta Derm Venereol. 1985; 65:409-412.

52. Bisgaard H, Kristensen J, Sondergaard J. The effect of leukotrienes C4 and D4 on microcirculatory flow in humans. Br J Dermatol. 1983; 109 Suppl 25:124-125. 53. Nettis E, Colanardi MC, Paradiso MT, Ferrannini A. Desloratadine in combination with montelukast in the treatment of chronic urticaria: a randomized, double-blind, placebo-controlled study. Clin Exp Allergy. 2004; 34:1401-1407. 54. Greaves MW, McDonald-Gibson W. Itch: role of prostaglandins. Br Med J. 1973; 22: 608-609.

55. Koro O, Dover JS, Francis DM, Kobza Black A, Kelly RW, Barr RM, Greaves 
MW. Release of prostaglandin D2 and histamine in a case of localized heat urticaria, and effect of treatments. Br J Dermatol. 1986; 115:721-728.

56. Hagermark O, Strandberg K, Hamberg M. Potentiation of itch and flare responses in human skin by prostaglandins E2 and $\mathrm{H} 2$ and a prostaglandin endoperoxide analog. J Invest Dermatol. 1977; 69: 527-530.

57. Hagermark O. Studies on experimental itch induced by kallikrein and bradykinin. Acta Derm Venereol. 1974; 54: 397-400.

58. Juhlin L, Michaelsson G. Cutaneous reactions to kallikrein, bradykinin and histamine in healthy subjects and in patients with urticaria. Acta Derm Venereol. 1969; 49: 26-36.

59. Fox A, Wotherspoon G, McNair K, Hudson L, Patel S, Gentry C, Winter J. Regulation and function of spinal and peripheral neuronal B1 bradykinin receptors in inflammatory mechanical hyperalgesia. Pain. 2003; 104:683-691.

60. Fjellner B, Hagermark O. Pruritus in polycythemia vera: treatment with aspirin and possibility of platelet involvement. Acta Derm Venereol. 1979; 59:505-512. 61. Weisshaar E, Dunker N, Domrose U, Neumann KH, Gollnick H. Plasma serotonin and histamine levels in hemodialysis-related pruritus are not significantly influenced by 5-HT3 receptor blocker and antihistaminic therapy. Clin Nephrol. 2003; 59:124129.

62. Gaspari AA, Lotze MT, Rosenberg SA, Stern JB, Katz SI. Dermatologic changes associated with interleukin 2 administration. JAMA. 1987; 258: 1624-1629.

63. Wahlgren CF, Scheynius A, Hagermark O. Antipruritic effect of oral cyclosporin A in atopic dermatitis. Acta Derm Venereol. 1990; 70:323-329. 
64. Teofoli P, De Pita O, Frezzolini A, Lotti T. Antipruritic effect of oral cyclosporin A in essential senile pruritus. Acta Derm Venereol. 1998; 78: 232.

65. Scholzen TE, Luger TA. Neutral endopeptidase and angiotensin-converting enzyme -key enzymes terminating the action of neuroendocrine mediators. Exp Dermatol. 2004;13 Suppl 4:22-26.

66. Walls AF, Brain SD, Desai A, Jose PJ, Hawkings E, Church MK, Williams TJ. Human mast cell tryptase attenuates the vasodilator activity of calcitonin gene-related peptide. Biochem Pharmacol. 1992; 43:1243-8.

67. Wallengren J. Prurigo: diagnosis and management. Am J Clin Dermatol. 2004; 5: $85-95$

68. Johansson O, Hilliges M, Stahle-Backdahl M. Intraepidermal neuron-specific enolase (NSE)-immunoreactive nerve fibres: evidence for sprouting in uremic patients on maintenance hemodialysis. Neurosci Lett. 1989; 99: 281-286.

69. Cappuggi P, Lotti T, Tsampau D et al. Capsaicin treatment of different dermatological affection with itching. Skin Pharmacol 1989; 2: 230.

70. Stander S, Luger T, Metze D. Treatment of prurigo nodularis with topical capsaicin. J Am Acad Dermatol. 2001; 44: 471-478.

71. Szallasi A.Vanilloid receptor ligands: hopes and realities for the future. Drugs Aging. 2001; 18: 561-573.

72. Astwazaturow M. Über paresthetische neuralgien und eine bezondere Form derselben- Nothalgia paresthetica. Nervenarzt (Berlin) 1934; 133: 88.

73. Massey EW, Pleet AB. Localized pruritus-notalgia paresthetica. Arch Dermatol. 1979; 115: 982-983.

74. Eisenberg E, Barmeir E, Bergman R. Notalgia paresthetica associated with nerve root impingement. J Am Acad Dermatol. 1997; 37:998-1000. 
75. Springall DR, Karanth SS, Kirkham N, Darley CR, Polak JM. Symptoms of notalgia paresthetica may be explained by increased dermal innervation. J Invest Dermatol. 1991; 97: 555-561.

76. Wallengren J. Treatment of notalgia paresthetica with topical capsaicin. J Am Acad Dermatol. 1991; 24:286-288.

77. Ulkar B, Yildiz Y, Kunduracioglu B. Meralgia paresthetica: a long-standing performance-limiting cause of anterior thigh pain in a soccer player. Am J Sports Med. 2003; 31: 787-789.

78. Boulware DR. Backpacking-induced paresthesias. Wilderness Environ Med. 2003; 14: 161-166.

79. Stein M, Shlamkovitch N, Finestone A, Milgrom C. Marcher's digitalgia paresthetica among recruits. Foot Ankle. 1989; 9: 312-313.

80. Massey EW, Pleet AB. Handcuffs and cheiralgia paresthetica. Neurology. 1978;

28: $1312-1313$.

81. Massey EW, O'Brian JT. Cheiralgia paresthetica in diabetes mellitus. Diabetes Care. 1978; 1: 365-366.

82. Waisman M. Solar pruritus of the elbows (Brachioradial summer pruritus). Arch Dermatol.1968; 98: 481-485.

83. Wallengren J. Brachioradial pruritus: a reccurrent solar dermopathy. J Am Acad Dermatol 1998; 39: 803- 806.

84. Heyl T. Brachioradial pruritus. Arch Dermatol 1983; 119: 115-116.

85. Fisher DA. Brachioradial pruritus wanted: a sure cause (and cure) for brachioradial pruritus. Int J Dermatol. 1997; 36: 817-818. 
86. Goodkin R, Wingard E, Bernhard JD. Brachioradial pruritus: cervical spine disease and neurogenic/neuropathic pruritus. J Am Acad Dermatol 2003; 48: 521524.

87. Walcyk PJ; Elpern DJ. Brachioradial pruritus: a tropical dermopathy. Br J Dermatol 1986; 115: 177-180.

88. Knight TE, Hayashi T. Solar (brachioradial) pruritus-response to capsaicin cream. Int J Dermatol 1994: 33: 206-209.

89. Bech-Thomsen N, Thomsen K. Solar pruritus. Acta Derm Venereol 1995; 75: 488-489.

90. Goodless DR, Eaglstein WH. Brachioradial pruritus: treatment with topical capsaicin. J Am Acad Dermatol. 1993; 29:783-784.

91. Wallengren J, Sundler F. Brachioradial pruritus is associated with a reduction of cutaneous inervation which normalizes during the symptom-free remissions. J Am Acad Dermatol 2005; 52: 142-145.

92. Wallengren J, Sundler F. Phototherapy induces loss of epidermal and dermal nerve fibers. Acta Derm Venereol (Stockh) 2004; 84: 111-115.

93. Bernhard JD. Brachioradial pruritus: A recurrent solar dermopathy. J Am Acad Dermatol. 1999; 41:658.

94. Upton AR, McComas AJ. The double crush in nerve entrapment syndromes. Lancet 1973; 2: 359-362.

95. Oaklander AL, Bowsher D, Galer B, Haanpaa M, Jensen MP. Herpes zoster itch: preliminary epidemiologic data. J Pain. 2003; 4: 338-343.

96. Bernstein JE, Korman NJ, Bickers DR, Dahl MV, Millikan LE. Topical capsaicin treatment of chronic postherpetic neuralgia. J Am Acad Dermatol. 1989; 21:265-70. 
97. Bastuji-Garin S, Ochonisky S, Bouche P, Gherardi RK, Duguet C, Djerradine Z, Poli F, Revuz J; Thalidomide Neuropathy Study Group. Incidence and risk factors for thalidomide neuropathy: a prospective study of 135 dermatologic patients. J Invest Dermatol. 2002; 119: 1020-1026.

98. King CA, Huff FJ, Jorizzo JL. Unilateral neurogenic pruritus: paroxysmal itching associated with central nervous system lesions. Ann Int Med 1982; 97: 222-223. 99. Massey EW. Unilateral neurogenic pruritus following stroke. Stroke. 1984; 15: 901-903.

100. Wallengren J, Tegner E, Sundler F. Cutaneous sensory nerve fibers are decreased in number after peripheral and central nerve damage. J Am Acad Dermatol. 2002; 46: 215-7.

101. Shapiro PE, Braun CW. Unilateral pruritus after a stroke. Arch Dermatol. 1987: 123; $1527-1530$.

102. Gupta MA, Guptat AK.The use of antidepressant drugs in dermatology. J Eur Acad Dermatol Venereol. 2001; 15: 512-518.

103. Zucker I, Yosipovitch G, David M, Gafter U, Boner G. Prevalence and characterization of uremic pruritus in patients undergoing hemodialysis: uremic pruritus is still a major problem for patients with end-stage renal disease. J Am Acad Dermatol. 2003; 49: 842-846.

104. Schrag A. Psychiatric aspects of Parkinson's disease-an update. J Neurol. 2004; 251: 795-804.

105. Darmani NA, Janoyan JJ, Kumar N, Crim JL. Behaviorally active doses of the CB1 receptor antagonist SR 141716A increase brain serotonin and dopamine levels and turnover. Pharmacol Biochem Behav. 2003; 75: 777-787. 
106. Calo' G, Guerrini R, Rizzi A, Salvadori S, Regoli D. Pharmacology of nociceptin and its receptor: a novel therapeutic target. Br J Pharmacol. 2000; 129: 1261-83. 107. Bernstein JE, Swift RM. Relief of intractable pruritus with naloxone. Arch Dermatol 1979; 115: 1366-1367.

108. Urbonas A, Schwartz RA, Szepietowski JC. Uremic pruritus-an update. Am J Nephrol. 2001; 5: 343-350.

109. Twycross R, Greaves MW, Handwerker H, Jones EA, Libretto SE, Szepietowski JC, Zylicz Z. Itch: scratching more than the surface. QJM. 2003; 96: 7-26.

\section{Legends}

Figure 1. Diagram of the course and termination of pruritoceptive information. Itch is conducted by intraepithelial mechanoinsensitive nerve fibres ascending to the lamina I in the dorsal horn of the spinal cord. The lamina I spinothalamic tract neurons cross over to the contralateral side and ascend to the thalamus. Neuronal projections from the ventral medial nucleus in thalamus terminate in sensorimotor cortex while neurons from the medial dorsal nucleus in thalamus terminate in the cingulate cortex.

Figure 2. Skin from the upper arm of a patient with brachioradial pruritus. A. Calcitonin gene-related peptide, CGRP -immunoreactive nerve fibres scattered beneath and inthe epidermis. B. Vanilloid receptor VR1-immunoreactive, kite-like structures beneath the epidermis. 
Figure 3. Schematic illustration of main mediators of neurogenic inflammation. When the thin intraepidermal nerve fibres become activated, the impulse flow is propagated to the central nervous system. Some of the impulses spread to adjacent branches of the nerve in retrograde direction through an axon reflex. Nerve transmitters are released in the skin and act as inflammatory mediators. Substance P induces a flare and weal reaction while CGRP induces a persistent erythema with pseudopodia resembling the one of prostaglandin PGE 2. Substance P stimulates mast cells to degranulate and the released histamine stimulates blood vessels and new neurons to release nerve transmitters. The reaction is potentiated by other mediators, such as bradykinin, cytokines, and serotonin released from the inflammatory cells. This cascade of events is dependent on the density of nerve fibres, on the occurrence of mast cells and on the concentration of inflammatory mediators.

Figure 4. Sensory nerve fibres in the gluteal skin, showing PGP 9.5 immunoreactivity (pan-neuronal marker). A. Before UV therapy and B. after 18 treatments with TL01. Figure 5. Schematic illustration of physiological and neuropathic itch. A. Normally, noxious stimuli in the periphery activate C-fibres and the impulses are transmitted to the spinal cord and to the brain.

B. Sometimes, the neurons can be activated without the involvement of peripheral nerve endings. Inflammation at this level can enhance neuronal excitability, causing repetitive activation of the $\mathrm{C}$-fibres. Here the neurons can start firing spontaneously as may be the case in brachioradial pruritus. Photodamaged nociceptors can start firing spontaneously and the nerve impulses generated in this way can also be amplified by neurogenic mechanisms elicited by nerve compression which is secondary to the 
cervical spine disease. Nerve fibres can start firing due to pressure; this is the case in such entrapment syndromes as notalgia paresthetica.

C. A lesion can also be located in the spinal ganglia as in herpes infection and postherpetic neuralgia or in spinal cord as in the burning sensation caused by treatment with thalidomide.

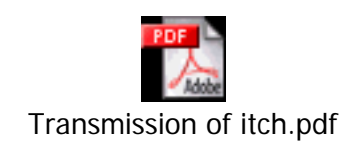

Figure 1
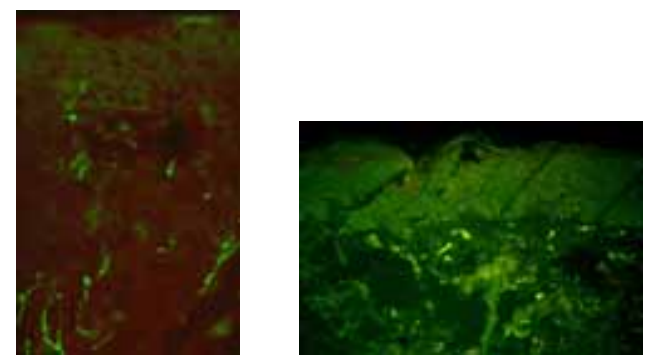

Figure 2 A, B

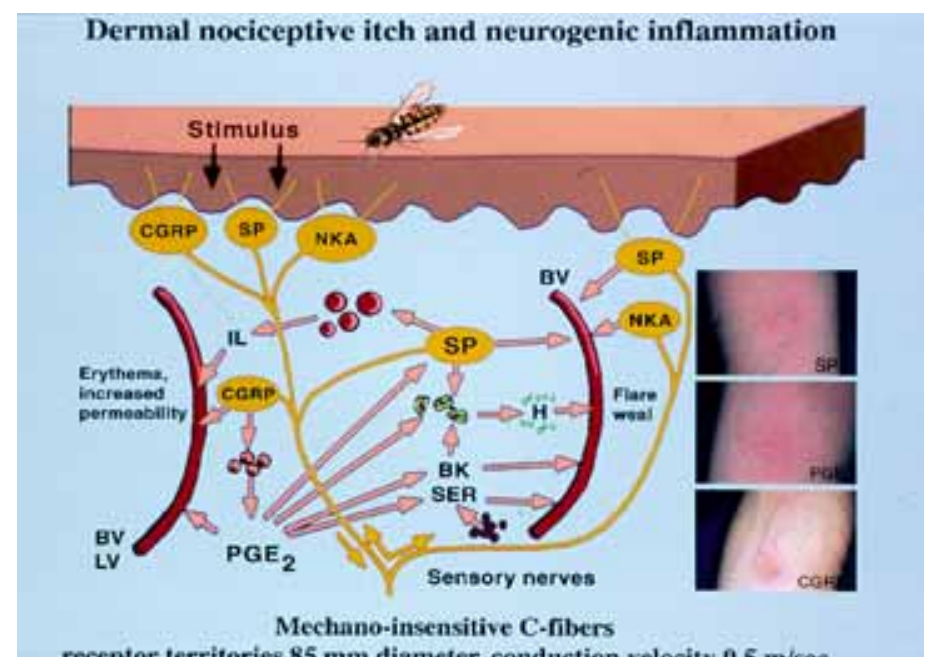

Figure 3. 

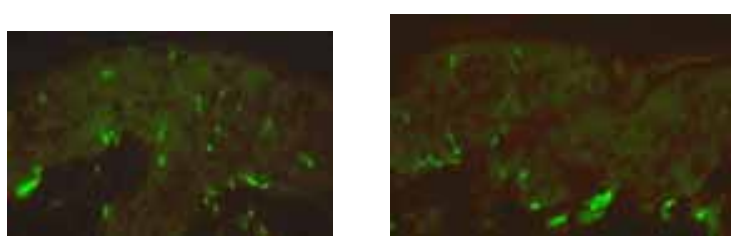

Figure 4 A, B

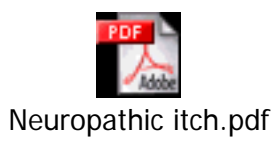

Figure 5 